Check for updates

Cite this: RSC Adv., 2017, 7, 32304

Received 13th May 2017

Accepted 16th June 2017

DOI: 10.1039/c7ra05423h

rsc.li/rsc-advances

\section{Naphthalimide-coumarin conjugate: ratiometric fluorescent receptor for self-calibrating quantification of cyanide anions in cells $\uparrow$}

\author{
Yasuhiro Shiraishi, iD *ab Naoto Hayashi, ${ }^{a}$ Masaki Nakahata, ${ }^{c}$ Shinji Sakai ${ }^{\mathrm{c}}$ \\ and Takayuki Hirai ${ }^{a}$
}

\begin{abstract}
Quantitative determination of toxic cyanide anions $\left(\mathrm{CN}^{-}\right)$in biological samples is an important subject. We synthesized a naphthalimide-coumarin conjugate with a simple imine linker (1), which behaves as a fluorescent receptor for ratiometric quantification of $\mathrm{CN}^{-}$. It exhibits green naphthalimide fluorescence at $533 \mathrm{~nm}$, originating from the excited-state intramolecular charge transfer (ESICT) from coumarin to naphthalimide fluorophores. Selective $\mathrm{CN}^{-}$addition to the imine linker affords an $\boldsymbol{\alpha}$-amino nitrile product. This suppresses ESICT and creates coumarin fluorescence at $444 \mathrm{~nm}$ and naphthalimide fluorescence at $533 \mathrm{~nm}$ originating from direct photoexcitation of the respective fluorophores. The emission intensity at $533 \mathrm{~nm}$ is maintained upon $\mathrm{CN}^{-}$addition and can be used as an internal standard for analysis. This ratiometric response enables self-calibrating $\mathrm{CN}^{-}$quantification based on the intensities of two emissions in solution and in cells. This facilitates rapid (within $3 \mathrm{~min}$ ), selective, and sensitive ratiometric detection of very low levels of $\mathrm{CN}^{-}(>1.8 \mu \mathrm{M})$.
\end{abstract}

\section{Introduction}

The cyanide anion $\left(\mathrm{CN}^{-}\right)$is very toxic ${ }^{1}$ and its binding to cytochrome units causes paralysis of cellular respiration ${ }^{2}$ and significant damage to the nervous system. ${ }^{3}$ Absorption of a very small amount of $\mathrm{CN}^{-}$, as little as 0.5-3.5 $\mathrm{mg}$ per kilogram of body weight, is enough to cause human death. ${ }^{4}$ Cyanides are, however, versatile reagents for synthesis ${ }^{5}$ and metallurgy. ${ }^{6}$ This often causes a release of $\mathrm{CN}^{-}$into the environment. The World Health Organization (WHO) therefore sets the maximum permissive level of cyanide in drinking water at $1.9 \mu \mathrm{M}^{7}$ Quantitative determination of $\mathrm{CN}^{-}$in environmental and biological samples by simple and rapid pretreatment and inexpensive instrumentation is a challenge.

Fluorometric analysis with a $\mathrm{CN}^{-}$-selective receptor is one promising method for this purpose because it facilitates simple quantification of $\mathrm{CN}^{-}$with a common fluorescence spectrometer. So far, a variety of off-on type fluorescent $\mathrm{CN}^{-}$receptors have been proposed; ${ }^{8}$ however, many of them show single-

\footnotetext{
${ }^{a}$ Research Center for Solar Energy Chemistry, Division of Chemical Engineering, Graduate School of Engineering Science, Osaka University, Toyonaka 560-8531, Japan. E-mail: shiraish@cheng.es.osaka-u.ac.jp

${ }^{b}$ Precursory Research for Embryonic Science and Technology (PRESTO), Japan Science and Technology Agency (JST), Saitama 332-0012, Japan

${ }^{c}$ Division of Chemical Engineering, Graduate School of Engineering Science, Osaka University, Toyonaka 560-8531, Japan

$\dagger$ Electronic supplementary information (ESI) available: Supplementary data (Fig. S1-S10), and Cartesian coordinates for molecules. See DOI: 10.1039/c7ra05423h
}

wavelength fluorescence and its intensity is used for quantification. The emission intensity is strongly affected by several factors such as instruments and receptor concentration; therefore, tedious calibration procedure is necessary on the respective instruments. In contrast, ratiometric receptor, which shows a new fluorescence in addition to the inherent one by the interaction with $\mathrm{CN}^{-}$, allow quantification just by monitoring the intensities of two emissions, where the effects of instruments and receptor concentration can be eliminated. Some ratiometric $\mathrm{CN}^{-}$receptors, which can be used in bulk solution, have been proposed; ${ }^{9}$ however, to the best of our knowledge, none of the receptor facilitates ratiometric $\mathrm{CN}^{-}$quantification in cells.

Here we report a first example of a fluorescent $\mathrm{CN}^{-}$receptor enabling ratiometric quantification in cells. Our strategy for the receptor design is a simple $\pi$-conjugation of two fluorophores with donor and acceptor characters, respectively, which are in the excited-state intramolecular charge transfer (ESICT). As shown in Scheme 1, a naphthalimide-coumarin conjugate with a simple imine linker (1), when dissolved in neutral media, exhibits a green naphthalimide fluorescence at $533 \mathrm{~nm}$ via ESICT. $\mathrm{CN}^{-}$addition to the imine moiety suppresses ESICT and allows direct photoexcitation of the respective fluorophores, creating a coumarin fluorescence at $444 \mathrm{~nm}$ and a naphthalimide fluorescence at $533 \mathrm{~nm}$. The $533 \mathrm{~nm}$ emission maintains its intensity. This facilitates ratiometric quantification of $\mathrm{CN}^{-}$in solution and cells based on the intensity of $533 \mathrm{~nm}$ emission as an internal standard. ${ }^{10}$ This allows rapid ( $3 \mathrm{~min}$ ), selective, and sensitive detection of 


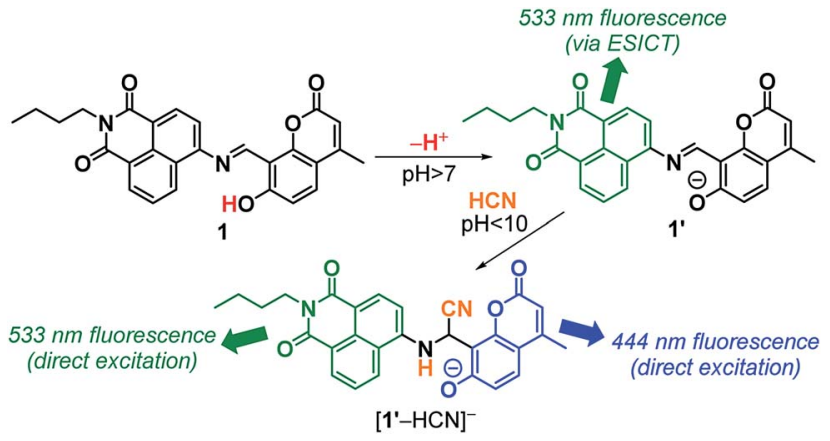

Scheme 1 Proposed mechanism for ratiometric fluorescence response of the receptor 1 upon reaction with $\mathrm{CN}^{-}$.

$\mathrm{CN}^{-}$as low as $1.8 \mu \mathrm{M}$, lower than the permissive level in drinking water set by WHO.

\section{Results and discussion}

\section{Synthesis and fluorescence properties}

The receptor 1 was synthesized by the procedure depicted in Scheme 2. 4-Amino- $N$-butyl-1,8-naphthalimide ${ }^{11}$ and 8-formyl-7hydroxy-4-methylcoumarin ${ }^{12}$ were dissolved in EtOH, and the solution was stirred at $80{ }^{\circ} \mathrm{C}$ for $4 \mathrm{~h}$. The solid formed was recovered by filtration and washed thoroughly with EtOH and $\mathrm{CH}_{2} \mathrm{Cl}_{2}$, affording 1 as orange solids with $14 \%$ yield. The purity of 1 was confirmed by ${ }^{1} \mathrm{H}$ NMR, ${ }^{13} \mathrm{C}$ NMR, and FAB-MS analysis (Fig. S1-S3, ESI $\dagger$ ).

$1(10 \mu \mathrm{M})$ was dissolved in a buffered water/MeCN mixture $(1 / 1 \mathrm{v} / \mathrm{v}$ ) with pH 7.0 (HEPES $0.1 \mathrm{M}$ ) and subjected for fluorescence measurements at $25{ }^{\circ} \mathrm{C}$. As shown in Fig. 1a (green line), 1, when photoexcited at $385 \mathrm{~nm}$, shows a green fluorescence centered at $533 \mathrm{~nm}$ with fluorescence quantum yield $\left(\Phi_{\mathrm{F}}\right)=0.16$. Addition of 200 equiv. of $\mathrm{CN}^{-}\left(\right.$as $n-\mathrm{Bu}_{4} \mathrm{~N}^{+}$ salt) to this solution followed by stirring for $5 \mathrm{~min}$ (blue line) creates a new emission at $444 \mathrm{~nm}\left(\Phi_{\mathrm{F}}=0.05\right)$ while maintaining the intensity of the $533 \mathrm{~nm}$ emission $\left(\Phi_{\mathrm{F}}=0.17\right)$. It is noted that addition of other nucleophiles scarcely changes the spectrum, indicating that $\mathrm{CN}^{-}$selectively creates the $444 \mathrm{~nm}$ emission. It is also noted that, as shown in Fig. 1b, the $444 \mathrm{~nm}$ emission enhanced selectively by $\mathrm{CN}^{-}$is unaffected by the other nucleophiles. This clearly suggests that 1 selectively detects $\mathrm{CN}^{-}$even in the presence of these contaminants.

Fig. 2 (top) shows the change in fluorescence spectra of $\mathbf{1}$ at $\mathrm{pH} 7.0$ with $\mathrm{CN}^{-}$concentrations. Stepwise addition of $\mathrm{CN}^{-}$

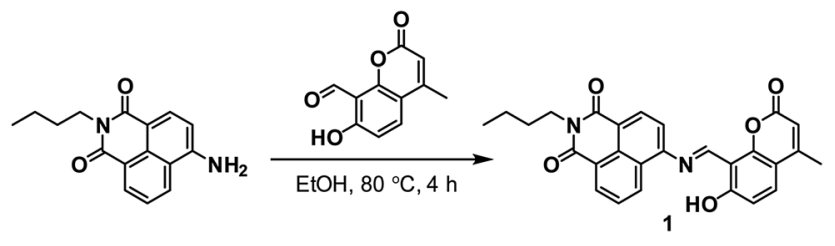

Scheme 2 Synthesis of the receptor 1.
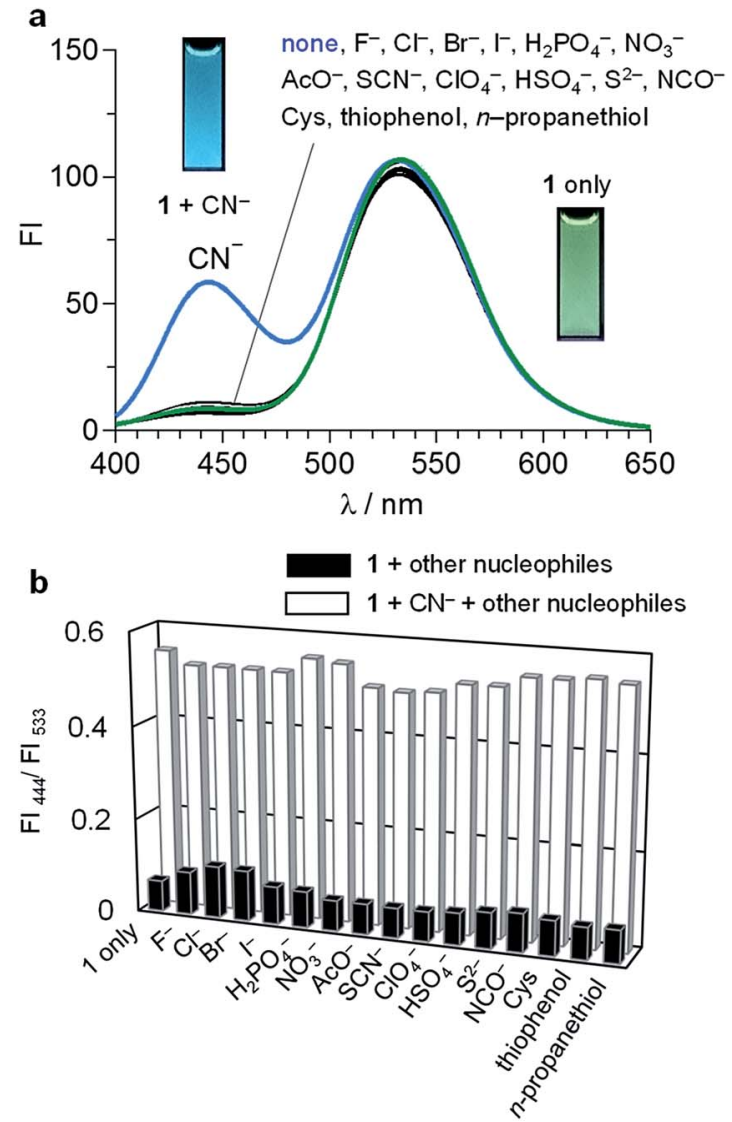

Fig. 1 (a) Fluorescence spectra $\left(\lambda_{\mathrm{ex}}=385 \mathrm{~nm}\right)$ of $1(10 \mu \mathrm{M})$ with 200 equiv. of each nucleophile in a buffered water/MeCN mixture $(1 / 1 \mathrm{v} / \mathrm{v}$; HEPES 0.1 M, pH 7.0) at $25^{\circ} \mathrm{C}$. (b) Intensity obtained (black) with 200 equiv. of each nucleophile and (white) 200 equiv. of $\mathrm{CN}^{-}$and other nucleophiles.

increases the intensity of the $444 \mathrm{~nm}$ fluorescence, while maintaining the intensity of the $533 \mathrm{~nm}$ fluorescence. As shown in Fig. 2 (bottom), plots of the ratio of fluorescence intensities $\left(\mathrm{FI}_{444} / \mathrm{FI}_{533}\right)$ versus the $\mathrm{CN}^{-}$concentrations show linear relationship, indicating that 1 allows accurate $\mathrm{CN}^{-}$ sensing at $\sim 4000 \mu \mathrm{M}$. The detection limit is determined to be $1.8 \mu \mathrm{M}$ based on the signal-to-noise $(\mathrm{S} / \mathrm{N})$ ratio using the equation $(\mathrm{DL}=3 \times \mathrm{SD} / S),{ }^{13}$ where $\mathrm{SD}$ is the standard deviation of blank analysis $\left(\mathrm{SD}=2.77 \times 10^{-4}, n=10\right)$ and $S$ is the slope of the intensity versus the $\mathrm{CN}^{-}$concentrations $(S=4.47$ $\times 10^{-4} \mu \mathrm{M}^{-1}$ ). This detection limit is lower than the maximum permissive level of cyanide in drinking water $(1.9 \mu \mathrm{M})$ set by WHO, ${ }^{7}$ although the present method cannot use pure water due to the low solubility of the receptor and requires a water/ MeCN (1:1) mixture for the analysis. Nevertheless, the receptor 1 facilitates sensitive $\mathrm{CN}^{-}$detection by ratiometric analysis. It must also be noted that 1 detects $\mathrm{CN}^{-}$very rapidly. Fig. S4 (ESI $\dagger$ ) shows the time course of the fluorescence intensity of 1 after addition of $\mathrm{CN}^{-}$. The intensity increases immediately after the $\mathrm{CN}^{-}$addition and almost terminates within $3 \mathrm{~min}$, suggesting that only $3 \mathrm{~min}$ assay facilitates $\mathrm{CN}^{-}$ sensing. 

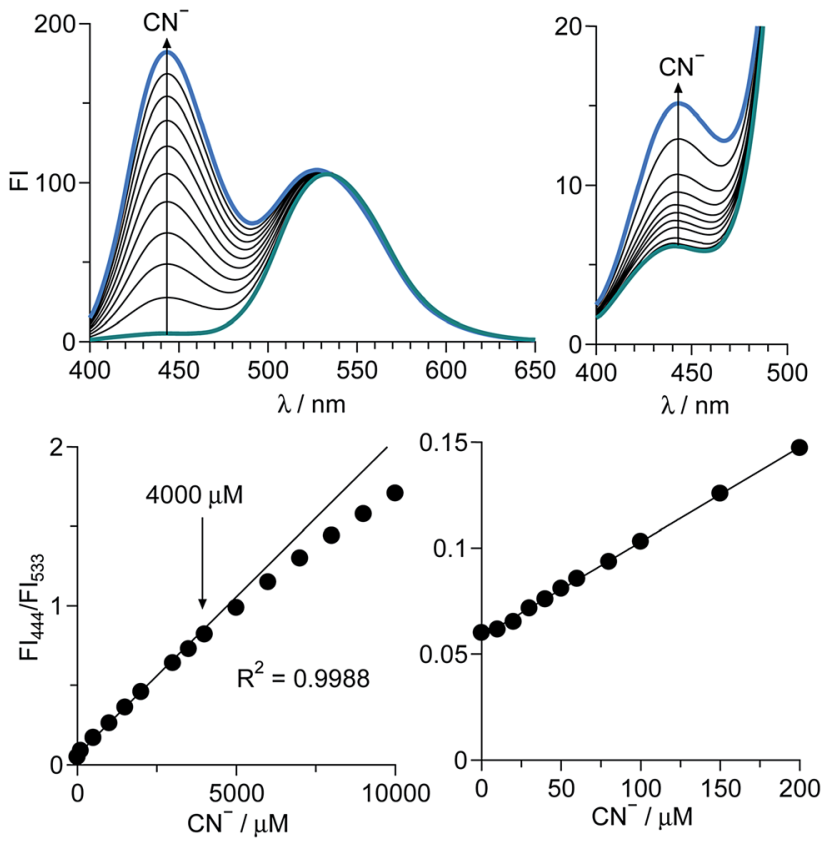

Fig. 2 Change in (top) fluorescence spectra $\left(\lambda_{\mathrm{ex}}=385 \mathrm{~nm}\right)$ and (bottom) the ratio of fluorescence intensity $\left(\mathrm{FI}_{444} / \mathrm{FI}_{533}\right)$ of $1(10 \mu \mathrm{M})$ with $\mathrm{CN}^{-}$concentration, measured in a buffered water/MeCN mixture $(1 / 1 \mathrm{v} / \mathrm{v}$; HEPES $0.1 \mathrm{M}, \mathrm{pH} 7.0)$ at $25^{\circ} \mathrm{C}$. The right figures show the enlarged images of the left figures.

\section{Mechanism for reaction with $\mathrm{CN}^{-}$}

As summarized in Scheme 1, the $\mathrm{CN}^{-}$-induced enhancement of the $444 \mathrm{~nm}$ emission for 1 is triggered by the addition of HCN to the imine moiety of $\mathbf{1}^{\prime}$ species, the deprotonated form of $\mathbf{1}$, producing $\left[\mathbf{1}^{\prime}-\mathrm{HCN}\right]^{-}$species. At $\mathrm{pH}>\mathbf{7 , 1}$ undergoes deprotonation of its $-\mathrm{OH}$ group since $\mathrm{p} K_{\mathrm{a}}$ of 7-hydroxycoumarin moiety is 7.8. ${ }^{14}$ The deprotonated $\mathbf{1}^{\prime}$ reacts with $\mathrm{HCN},{ }^{15}$ and gives an $\alpha$ amino nitrile product $\left[\mathbf{1}^{\prime}-\mathrm{HCN}\right]^{-}$. The $\mathrm{HCN}$ addition is confirmed by fluorescence analysis of 1 with $\mathrm{CN}^{-}$at different pH. As shown in Fig. S5 (ESI $\dagger$ ), the fluorescence enhancement of 1 by $\mathrm{CN}^{-}$is very small at $\mathrm{pH}>10$. This suggests that deprotonation of $\mathrm{HCN}\left(\mathrm{HCN}+\mathrm{OH}^{-} \leftrightarrow \mathrm{H}_{2} \mathrm{O}+\mathrm{CN}^{-} ; \mathrm{p} K_{\mathrm{a}}=9.2\right)$ suppresses the $\mathrm{HCN}$ addition to $\mathbf{1}^{\prime}$, clearly supporting the reaction mechanism in Scheme 1.

The HCN addition to the imine moiety of $\mathbf{1}^{\prime}$, producing the $\left[\mathbf{1}^{\prime}-\mathrm{HCN}\right]^{-}$species, is confirmed by NMR analysis. ${ }^{1} \mathrm{H}$ NMR charts of $\mathbf{1}$ and $\left[\mathbf{1}^{\prime}-\mathrm{HCN}\right]^{-}$were shown in Fig. 3 , where the $2 \mathrm{D}$ COSY spectra were used for the assignment of the respective chemical shifts (Fig. S6 and S7, ESI†). As shown in Fig. 3a, 1 measured in DMSO- $\mathrm{d}_{6}$ shows imine $\mathrm{H}^{\mathrm{a}}$ proton at $9.5 \mathrm{ppm}$. As shown in Fig. $3 \mathrm{~b}$, the $\left[\mathbf{1}^{\prime}-\mathrm{HCN}\right]^{-}$species shows significant upfield shift of the $\mathrm{H}^{\mathrm{a}}$ proton $(6.1 \mathrm{ppm})$. This suggests that the imine moiety of $\mathbf{1}^{\prime}$ reacts with HCN. As shown in Fig. $4,{ }^{13} \mathrm{C}$ NMR charts of $\mathbf{1}$ also show upfield shift of the imine $\mathrm{CH}$ carbon $(160 \mathrm{ppm} \rightarrow 42 \mathrm{ppm}$ ) by the reaction with HCN and creates a new peak for the $-C \mathrm{~N}$ carbon at $119 \mathrm{ppm}$. This further supports the HCN addition to the imine moiety. The 1:1 reaction of $\mathbf{1}^{\prime}$ with $\mathrm{HCN}$ is confirmed by FAB-MS analysis. As shown in Fig. S8 (ESI $\dagger$ ), the product shows a peak at $\mathrm{m} / z 481.2$
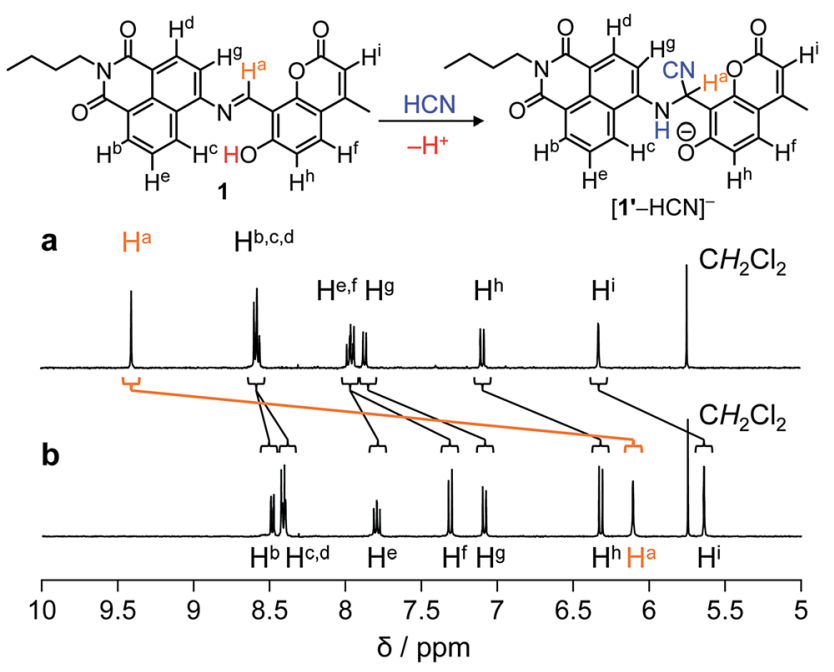

Fig. $3{ }^{1} \mathrm{H}$ NMR chart of $1(10 \mathrm{mM})$ measured (a) without and (b) with 1 equiv. of $\mathrm{CN}^{-}\left(400 \mathrm{MHz}, 30^{\circ} \mathrm{C}\right.$, DMSO- $\left.\mathrm{d}_{6}\right)$.

attributable to the $\left[\mathbf{1}^{\prime}+\mathrm{HCN}\right]^{-}$species. The result strongly supports the 1 : 1 reaction between $\mathbf{1}^{\prime}$ and $\mathrm{HCN}$.

\section{Mechanism for fluorometric response}

The ratiometric fluorescence response of 1 upon $\mathrm{CN}^{-}$addition can be explained by the mechanism summarized in Scheme 1 . Without $\mathrm{CN}^{-}$, the deprotonated $\mathbf{1}^{\prime}$ shows the $533 \mathrm{~nm}$ fluorescence from the excited-state naphthalimide moiety, formed by the excited-state intramolecular charge transfer (ESICT) from the coumarin to naphthalimide moiety. In contrast, the formation of $\left[\mathbf{1}^{\prime}-\mathrm{HCN}\right]^{-}$by the $\mathrm{HCN}$ addition to the imine moiety of $\mathbf{1}^{\prime}$ leads to a cleavage of the $\pi$-conjugation between the coumarin and naphthalimide moieties and suppresses ESICT. This thus creates two emissions from the directly photoexcited coumarin and naphthalimide moieties, respectively. Ab initio calculations based on the time-dependent density functional theory (TDDFT) ${ }^{\mathbf{1 6}}$ confirm the mechanism. As shown in Table S1 $\left(\mathrm{ESI}^{\dagger}\right)$, singlet electronic transition of $\mathbf{1}^{\prime}$ is mainly contributed by HOMO-2 $\rightarrow$ LUMO $\left(\mathrm{S}_{0} \rightarrow \mathrm{S}_{3}\right)$ transition. Its energy $(2.99 \mathrm{eV}$, $415 \mathrm{~nm})$ is similar to the observed $\lambda_{\max }(425 \mathrm{~nm})$ of the absorption spectrum of $\mathbf{1}^{\prime}$ (Fig. S9, ESI $\dagger$ ). As summarized in Fig. 5 (left), $\pi$-electrons of HOMO-2 of $\mathbf{1}^{\prime}$ are delocalized over the two fluorophores, but those of LUMO are localized on the naphthalimide moiety. This indicates that the ESICT from the photoexcited coumarin to naphthalimide moiety indeed creates the $533 \mathrm{~nm}$ naphthalimide fluorescence.

In contrast, as shown in Table S1 (ESI $\dagger$ ), singlet transition of $\left[\mathbf{1}^{\prime}-\mathrm{HCN}\right]^{-}$species is contributed predominantly by HOMO-1 $\rightarrow$ LUMO $\left(\mathrm{S}_{0} \rightarrow \mathrm{S}_{2}\right)$ and HOMO $\rightarrow$ LUMO+1 $\left(\mathrm{S}_{0} \rightarrow \mathrm{S}_{4}\right)$ transitions. The former transition energy $(2.88 \mathrm{eV}, 431 \mathrm{~nm})$ is close to that for the observed $\lambda_{\max }(425 \mathrm{~nm})$ in the absorption spectrum of $\left[\mathbf{1}^{\prime}-\mathrm{HCN}\right]^{-}$(Fig. S9, ESI $\dagger$ ). As shown in Fig. 5 (right, green), $\pi$ electrons of both HOMO-1 and LUMO are localized on the naphthalimide moiety, indicating that this absorption is attributable to $\pi, \pi^{*}$-transition of naphthalimide moiety. The $533 \mathrm{~nm}$ fluorescence of the $\left[\mathbf{1}^{\prime}-\mathrm{HCN}\right]^{-}$species therefore 


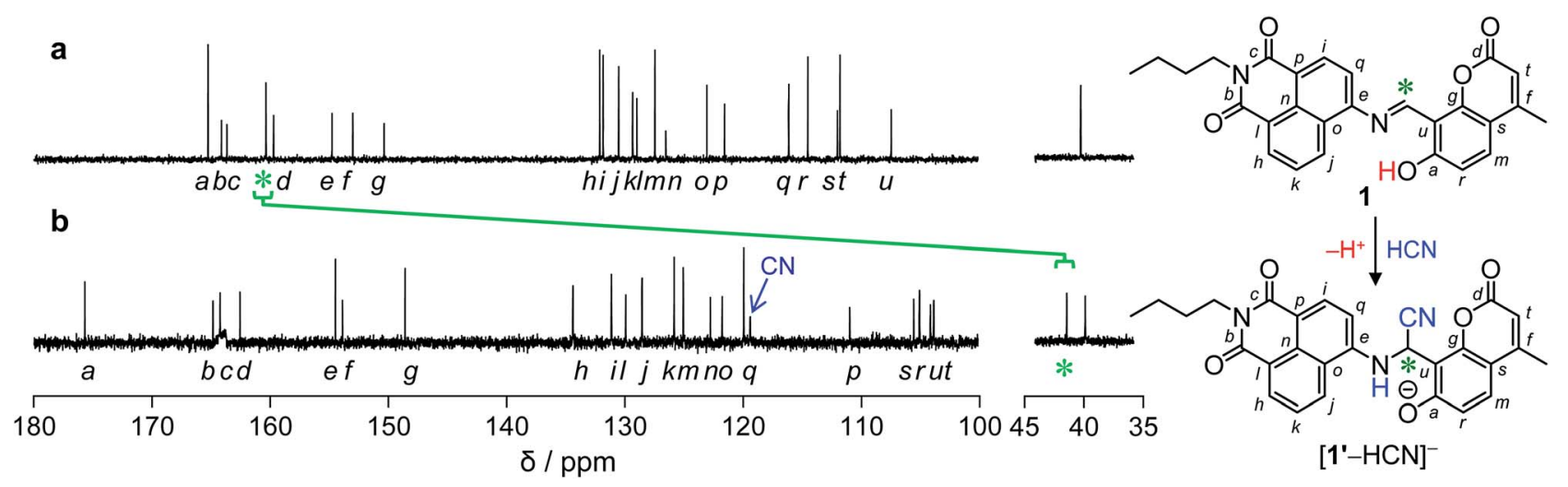

Fig. $4{ }^{13} \mathrm{C} \mathrm{NMR}$ chart of (a) 1 and (b) 1 with 1 equiv. of $\mathrm{CN}^{-}\left(100 \mathrm{MHz}, 30{ }^{\circ} \mathrm{C}, \mathrm{CDCl}_{3}\right)$.

originates from the directly photoexcited naphthalimide moiety. In contrast, the energy for HOMO $\rightarrow$ LUMO+1 transition $(3.43 \mathrm{eV}, 361 \mathrm{~nm})$ is also close to the observed $\lambda_{\max }(368 \mathrm{~nm})$ for the $\left[\mathbf{1}^{\prime}-\mathrm{HCN}\right]^{-}$absorption. As shown in Fig. 5 (right, blue), $\pi$ electrons of both HOMO and LUMO+1 are localized on the coumarin moiety, indicating that this is attributable to $\pi, \pi^{*}$ transition of the coumarin moiety. The $444 \mathrm{~nm}$ fluorescence of $\left[\mathbf{1}^{\prime}-\mathrm{HCN}\right]^{-}$therefore originates from the directly photoexcited coumarin moiety. These findings suggest that $\mathbf{1}^{\prime}$ shows $533 \mathrm{~nm}$ naphthalimide fluorescence through ESICT, while the [1'$\mathrm{HCN}]^{-}$species shows the $533 \mathrm{~nm}$ and $444 \mathrm{~nm}$ fluorescence from the directly photoexcited naphthalimide and coumarin moieties, respectively. The intensities of the $533 \mathrm{~nm}$ emission from both species are identical and, hence, the emission can be used as an internal standard for ratiometric quantification of $\mathrm{CN}^{-}$.

\section{$\mathbf{C N}^{-}$quantification in cells}

The receptor $\mathbf{1}$ also facilitates quantification of $\mathrm{CN}^{-}$in cells. HeLa cells were incubated in DMF containing $1(100 \mu \mathrm{M})$ and different concentrations of $\mathrm{CN}^{-}(0-90 \mu \mathrm{M})$ for $30 \mathrm{~min}$ at $37^{\circ} \mathrm{C}$, and were washed with PBS (pH 7.4). The obtained cells were monitored by fluorescence microscopy at a blue channel $\left(\lambda_{\mathrm{ex}}=\right.$ $\left.360 \mathrm{~nm} ; \lambda_{\mathrm{em}}=460 \mathrm{~nm}\right)$ and a green channel $\left(\lambda_{\mathrm{ex}}=470 \mathrm{~nm} ; \lambda_{\mathrm{em}}\right.$ $=535 \mathrm{~nm}$ ), respectively. As shown in the bottom of Fig. 6, the cell images monitored at a green channel show similar emission intensities regardless of the $\mathrm{CN}^{-}$concentrations. In contrast, as shown in the blue channel images (top), the emission intensity increases with increasing the $\mathrm{CN}^{-}$concentrations. The emission intensities of each cell (at least 10 cells) were determined by the equipped BZ-II Analyzer software (Keyence), and their average intensities $\left(\mathrm{FI}_{460}\right.$ and $\left.\mathrm{FI}_{535}\right)$ were calculated. Fig. 6k shows the change in the ratio of the emission intensity $\left(\mathrm{FI}_{460} / \mathrm{FI}_{535}\right)$ with the $\mathrm{CN}^{-}$concentrations. A linear relationship $\left(R^{2}=0.9979\right)$ indicates that 1 facilitates accurate quantification of $\mathrm{CN}^{-}$in cells based on the self-calibrating method.

To clarify the toxicity of the cell treatment, viability of the HeLa cells before and after treatment with DMF solution containing $\mathbf{1}$ was determined. A Trypan blue solution was added to the cells, and the respective live and dead cells were counted by Countess II FL Automated Cell Counter. As reported, ${ }^{8 c, 9 c-f}$ some early-reported $\mathrm{CN}^{-}$receptors exhibit low cytotoxicity after the treatment with aqueous solution containing the receptors. However, in our case, the cell viability after the treatment was

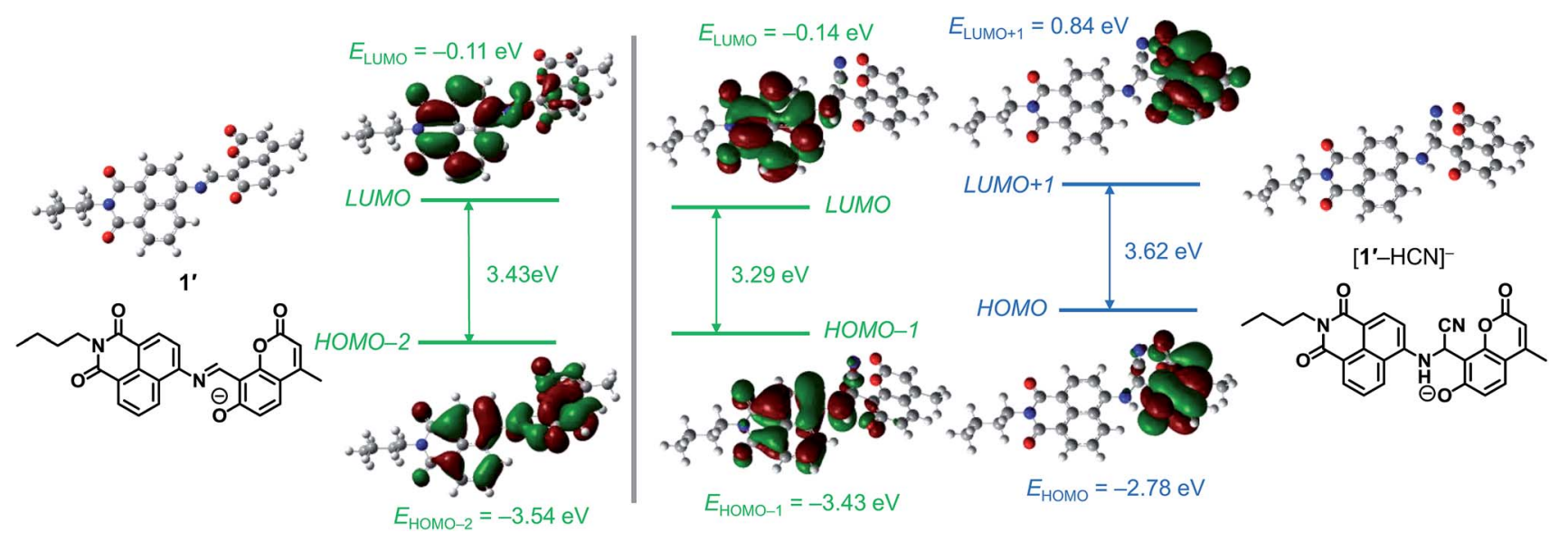

Fig. 5 Energy diagrams and interfacial plots of main molecular orbitals of (left) $1^{\prime}$ and (right) $\left[1^{\prime}-\mathrm{HCN}\right]^{-}$, calculated at the DFT level (B3LYP/6$31+G *)$. 

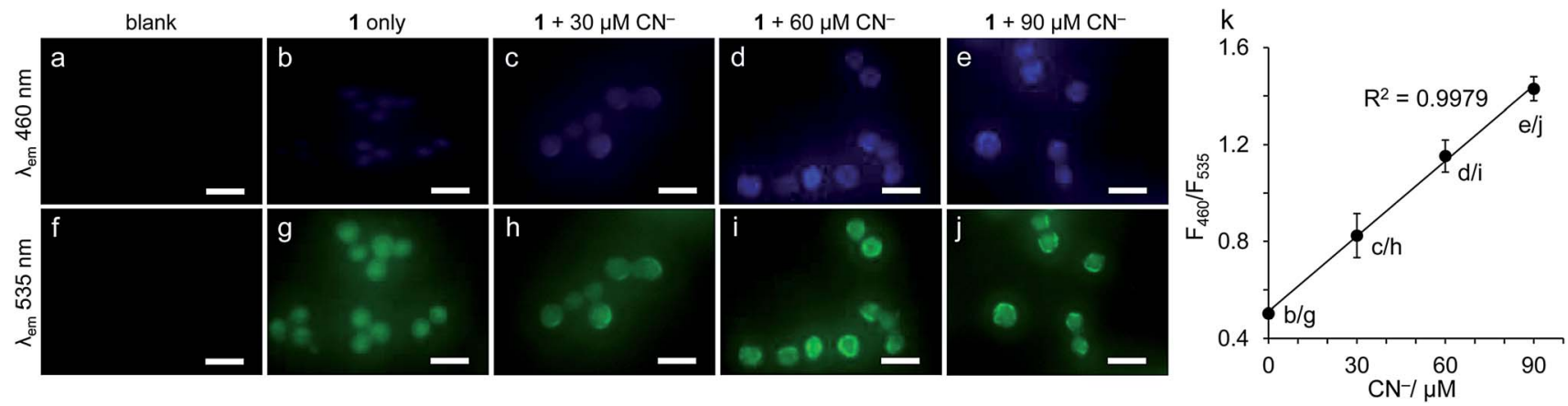

Fig. 6 Fluorescence microscope images of HeLa cells incubated with $1(100 \mu \mathrm{M}, \mathrm{DMF})$ and different concentration of $\mathrm{CN}^{-}(0-90 \mu \mathrm{M})$, monitored $(a-e)$ at a blue channel $\left(\lambda_{\mathrm{ex}}=360 \mathrm{~nm} ; \lambda_{\mathrm{em}}=460 \mathrm{~nm}\right)$ and $(\mathrm{f}-\mathrm{j})$ at a green channel $\left(\lambda_{\mathrm{ex}}=470 \mathrm{~nm} ; \lambda_{\mathrm{em}}=535 \mathrm{~nm}\right)$. The respective images were obtained after incubation for $30 \mathrm{~min}$ at $37^{\circ} \mathrm{C}$, followed by washing with PBS (pH 7.4). (k) Change in the ratio of fluorescence intensity $\left(\mathrm{FI}_{460} / \mathrm{Fl}_{535}\right)$ of 1 as a function of $\mathrm{CN}^{-}$concentrations. The scale bars are set at $20 \mu \mathrm{m}$.

only ca. $4 \%$, as summarized in Fig. S10 (ESI $\dagger$ ). This means that the cell treatment with DMF solution containing 1 leads to a loss of the functionality for almost all of the cells. In our case, the use of DMF with high cytotoxicity is necessary for permeation of the receptor into the cells due to its low solubility in water. Living cell imaging is therefore not facilitated by the present receptor $\mathbf{1 .}$

\section{Conclusion}

We synthesized a simple naphthalimide-coumarin dyad (1) behaving as a ratiometric fluorescent receptor for $\mathrm{CN}^{-}$quantification. The original longer-wavelength fluorescence is unaffected by $\mathrm{CN}^{-}$, while the shorter-wavelength fluorescence selectively increases by the $\mathrm{CN}^{-}$addition. This thus allows selfcalibrating quantification of $\mathrm{CN}^{-}$with the longer-wavelength emission as an internal standard. The receptor facilitates rapid, selective, and sensitive $\mathrm{CN}^{-}$quantification even in cells. The molecular design presented here based on simple conjugation of two fluorophores controlling the invariable and variable emissions towards $\mathrm{CN}^{-}$would contribute to the creation of more efficient receptors for accurate $\mathrm{CN}^{-}$quantification in environmental and biological samples.

\section{Experimental}

\section{General}

All anions were used as $n-\mathrm{Bu}_{4} \mathrm{~N}^{+}$or $\mathrm{Na}^{+}$salts. Fluorescence spectra were measured on a JASCO FP-6500 fluorescence spectrophotometer with a $10 \mathrm{~mm}$ path length cell (both excitation and emission slit widths, $5.0 \mathrm{~nm}$ ) at $298 \pm 1 \mathrm{~K}$ using a temperature controller. All measurements were performed under aerated condition. ${ }^{\mathbf{1 7}}$ Absorption spectra were measured on an UV-visible photodiode-array spectrometer (Shimadzu; Multispec-1500) equipped with a temperature controller (S1700). ${ }^{18}{ }^{1} \mathrm{H}$ and ${ }^{13} \mathrm{C}$ NMR charts were obtained using a JEOL JNM-ECS400 spectrometer. FAB-MS analysis was performed on a JEOL JMS 700 Mass Spectrometer. Fluorescence images of HeLa cells were obtained on fluorescence microscopy (BIOREVE BZ-9000, Keyence). ${ }^{19}$ Mean fluorescent intensities on the obtained images were determined using BZ-II Analyzer software (Keyence) by measuring the fluorescent intensity of at least 10 cells per photograph. Fluorescence quantum yields $\left(\Phi_{\mathrm{F}}\right)$ were determined with Rhodamine B (in EtOH) as a standard. ${ }^{20}$

\section{Synthesis of the receptor 1 [7-hydroxy-4-methyl-8-(( $N$-butyl-} 1,8-naphthalimide-4-ylimino)methyl)coumarin]

4-Amino- $N$-butyl-1,8-naphthalimide ( $57 \mathrm{mg}, 0.2 \mathrm{mmol})^{\mathbf{1 1}}$ and 8formyl-7-hydroxy-4-methylcoumarin $(43 \mathrm{mg}, 0.2 \mathrm{mmol})^{12}$ were dissolved in EtOH $(3 \mathrm{~mL})$, and the solution was stirred at $80^{\circ} \mathrm{C}$ for $4 \mathrm{~h}$. The solid formed was recovered by filtration and washed thoroughly with EtOH and $\mathrm{CH}_{2} \mathrm{Cl}_{2}$, affording 1 as orange solids. Yield: $13.4 \mathrm{mg}$ (14.1\%). ${ }^{1} \mathrm{H}$ NMR (400 MHz, DMSO-d ${ }_{6}, \mathrm{TMS}$ ), $\delta$ (ppm): 14.10 (1H, s), $9.41(1 \mathrm{H}, \mathrm{s}), 8.58(3 \mathrm{H}, \mathrm{t}, J=7.1 \mathrm{~Hz}), 7.97-$ $7.95(2 \mathrm{H}, \mathrm{m}), 7.87(1 \mathrm{H}, \mathrm{d}, J=7.8 \mathrm{~Hz}), 7.09(1 \mathrm{H}, \mathrm{d}, J=8.8 \mathrm{~Hz})$, $6.33(1 \mathrm{H}, \mathrm{d}, J=1.0 \mathrm{~Hz}), 4.08(2 \mathrm{H}, \mathrm{t}, J=7.8 \mathrm{~Hz}), 2.48-2.45(3 \mathrm{H}$, $\mathrm{m}), 1.68-1.61(2 \mathrm{H}, \mathrm{m}), 1.43-1.35(2 \mathrm{H}, \mathrm{m}), 0.95(3 \mathrm{H}, \mathrm{t}, J=7.1 \mathrm{~Hz})$. ${ }^{1} \mathrm{C}$ NMR (100 MHz, DMSO-d 6 , TMS) $\delta$ (ppm): 165.3, 164.1, 163.7, 160.3 , 159.7, 154.8, 153.0, 150.3, 132.1, 131.8, 130.5, 129.3, $128.9,127.4,126.5,123.0,121.5,116.0,114.4,111.9,111.7$, 107.4, 40.4, 30.3, 20.4, 19.0, 13.9. FAB-MS: $m / z$ : calcd for $\mathrm{C}_{27} \mathrm{H}_{23} \mathrm{~N}_{2} \mathrm{O}_{5}{ }^{+}\left(1+\mathrm{H}^{+}\right)^{+}$455.5; found: 455.2; HRMS $\left(\mathrm{FAB}^{+}\right): m / z$ : calcd for $\mathrm{C}_{27} \mathrm{H}_{23} \mathrm{~N}_{2} \mathrm{O}_{5}{ }^{+}\left(1+\mathrm{H}^{+}\right)^{+}$: 455.1601; found; 455.1605 .

\section{Calculation details}

$A b$ initio calculations were performed with tight convergence criteria at the DFT level within the Gaussian 03 package, using the B3LYP/6-31+G(D) basis set for all atoms. The excitation energies and oscillator strengths of the compounds were calculated by TDDFT at the same level of optimization. Cartesian coordinates are summarized at the end of ESI. $\dagger$

\section{Cell culture and fluorescence microscopy}

HeLa cells were grown in Dulbecco's modified eagle's medium (DMEM) supplemented with 10\% fetal bovine serum on cover slip in $60 \mathrm{~mm}$ dishes. The trypsinized cells were incubated with DMF containing $1(100 \mu \mathrm{M})$ and required amount of $\mathrm{CN}^{-}$for 20 min at $37^{\circ} \mathrm{C}$ in humidified air containing $5 \% \mathrm{CO}_{2}$. The cells were then washed with PBS for three times and subjected for 
observation using BIOREVE BZ-9000 Fluorescence Microscope apparatus.

\section{Cell viability test}

Trypsinized HeLa cells were incubated with DMF containing 1 $(100 \mu \mathrm{M})$ for $20 \mathrm{~min}$ at $37{ }^{\circ} \mathrm{C}$ in humidified air containing $5 \%$ $\mathrm{CO}_{2}$. After washing with PBS for three times, a Trypan blue solution was added to the cells. The respective live and dead cells were counted using the Countess II FL Automated Cell Counter.

\section{Acknowledgements}

This work was supported by the Grant-in Aid for Scientific Research (No. 15K06556) from the Ministry of Education, Culture, Sports, Science and Technology, Japan (MEXT).

\section{Notes and references}

1 A. Ishii, H. Seno, K. Watanabe-Suzuki, O. Suzuki and T. Kumazawa, Anal. Chem., 1998, 70, 4873-4876.

2 F. Wang, L. Wang, X. Chen and J. Yoon, Chem. Soc. Rev., 2014, 43, 4312-4324.

3 R. Badugu, J. R. Lakowicz and C. D. Geddes, J. Am. Chem. Soc., 2005, 127, 3635-3641.

$4 \mathrm{~W}$. Kaim and B. Schwederski, Bioinorganic Chemistry: Inorganic Elements in the Chemistry of Life, John Wiley \& Sons Ltd., England, 1991, p. 208.

5 Z. Xu, X. Chen, H. N. Kim and J. Yoon, Chem. Soc. Rev., 2010, 39, 127-137.

6 H. Hachiya, S. Ito, Y. Fushinuki, T. Masadome, Y. Asano and T. Imato, Talanta, 1999, 48, 997-1004.

7 WHO, Guidelines for Drinking-Water Quality, World Health Organization, Geneva, Switzerland, 2011, p. 342.

8 (a) C. H. Lee, H. J. Yoon, J. S. Shim and W. D. Jang, Chem.Eur. J., 2012, 18, 4513-4516; (b) L. Wang, J. Zheng, S. Yang, C. Wu, C. Liu, Y. Xiao, Y. Li, Z. Qing and R. Yang, ACS Appl. Mater. Interfaces, 2015, 7, 19509-19515; (c) H. Agarwalla, M. Gangopadhyay, D. K. Sharma, S. K. Basu, S. Jadhav, A. Chowdhury and A. Das, J. Mater. Chem. B, 2015, 3, 9148-9156; (d) D. Wang, J.-Q. Zheng, X. Yan, X.-J. Zheng and L.-P. Jin, RSC Adv., 2015, 5, 64756-64762; (e) W. Yang, Z. Cheng, Y. Xu, J. Shao, W. Zhou, J. Xie and M. Li, New J. Chem., 2015, 39, 7488-7494; (f) S. Wang, H. Xu, Q. Yang, Y. Song and Y. Li, RSC Adv., 2015, 5,
47990-47996; (g) R. Kaushik, A. Ghosh, A. Singh, P. Gupta, A. Mittal and D. A. Jose, ACS Sens., 2016, 1, 1265-1271.

9 (a) X. Cheng, R. Tang, H. Jia, J. Feng, J. Qin and Z. Li, ACS Appl. Mater. Interfaces, 2012, 4, 4387-4392; (b) J. Chao, Z. Li, Y. Zhang, F. Huo, C. Yin, H. Tong and Y. Liu, Sens. Actuators, B, 2016, 228, 192-199; (c) A. K. Mahapatra, K. Maiti, S. K. Manna, R. Maji, C. Das Mukhopadhyay, B. Pakhira and S. Sarkar, Chem.-Asian J., 2014, 9, 36233632; (d) A. K. Mahapatra, K. Maiti, R. Maji, S. K. Manna, S. Mondal, S. S. Ali and S. Manna, RSC Adv., 2015, 5, 24274-24280; (e) B. Vidya, M. Iniya, G. Sivaraman, R. V. Sumesh and D. Chellappa, Sens. Actuators, B, 2017, 242, 434-442; (f) H. Li, P. Zhao, N. Zou, H. Wang and K. Sun, Tetrahedron Lett., 2017, 58, 30-34.

10 (a) S. S. Pandey, S. N. Baker, S. S. Pandey and G. A. Baker, Chem. Commun., 2012, 48, 7043; (b) G. Ke, Z. Zhu, W. Wang, Y. Zou, Z. Guan, S. Jia, H. Zhang, X. Wu and C. J. Yang, ACS Appl. Mater. Interfaces, 2014, 6, 1532915334; (c) K. Zhang, T. Yu, F. Liu, M. Sun, H. Yu, B. Liu, Z. Zhang, H. Jiang and S. Wang, Anal. Chem., 2014, 86, 11727-11733; (d) Y. Wang, C. Zhang, X. Chen, B. Yang, L. Yang, C. Jiang and Z. Zhang, Nanoscale, 2016, 8, 59775984.

11 L. Cui, Z. Peng, C. Ji, J. Huang, D. Huang, J. Ma, S. Zhang, X. Qian and Y. Xu, Chem. Commun., 2014, 50, 1485-1487.

12 Y. Shiraishi, M. Nakamura, T. Kogure and T. Hirai, New J. Chem., 2016, 40, 1237-1243.

13 N. Sharma, S. I. Reja, V. Bhalla and M. Kumar, Dalton Trans., 2014, 43, 15929-15936.

14 M. Adamczyk, M. Cornwell, J. Huff, S. Rege and T. V. S. Rao, Bioorg. Med. Chem. Lett., 1997, 7, 1985-1988.

15 (a) A. Strecker, Justus Liebigs Ann. Chem., 1850, 75, 27-45; (b) D. Enders and J. P. Shilvock, Chem. Soc. Rev., 2000, 29, 359373.

16 R. E. Stratmann, G. E. Scuseria and M. J. Frisch, J. Chem. Phys., 1998, 109, 8218-8224.

17 Y. Shiraishi, M. Nakamura, K. Yamamoto and T. Hirai, Chem. Commun., 2014, 50, 11583-11586.

18 Y. Shiraishi, K. Tanaka, E. Shirakawa, Y. Sugano, S. Ichikawa, S. Tanaka and T. Hirai, Angew. Chem., Int. Ed., 2013, 52, 8304-8308.

19 Y. Liu, S. Sakai, S. Kawa and M. Taya, Anal. Chem., 2014, 86, 11592-11598.

20 (a) A. Proutiere, E. Megnassan and H. Hucteau, J. Phys. Chem., 1992, 96, 3485-3489; (b) B. Bag and P. K. Bharadwaj, J. Phys. Chem. B, 2005, 109, 4377-4390. 